\title{
Construction and validation of an educational leaflet for treatment of venous ulcer
}

Construção e validação de um folheto educativo para tratamento de úlcera venosa

Construcción y validación de un folleto educativo para el tratamiento de la úlcera venosa

Uiara Aline de Oliveira Kaizer ${ }^{1 *}$, Elaine Aparecida Rocha Domingues ${ }^{2}$

ORCID IDS

Kaizer UAO (iD https://orcid.org/0000-0002-9115-8043

Domingues EAR (DD https://orcid.org/0000-0002-7589-2344

\section{HOW TO CITE}

Kaizer UAO; Domingues EAR (2019) Construction and validation of an educational leaflet for treatment of venous ulcer. ESTIMA, Braz.

J. Enterostomal Ther., 17: e1619. https://doi.org/10.30886/estima. v17.677_IN

\begin{abstract}
Objective: To build and validate an educational leaflet for treatment of patients with ulcer of venous etiology. Methods: Methodological study, developed in two stages: construction of the educational leaflet by literature review and content validation of the material by judges specializing in the subject. Results: The instrument obtained a Content Validity Index (CVI) above 0.80; only one item was modified after the judges' suggestion. Conclusion: The educational leaflet was presented to be understandable and comprehensive for the content.
\end{abstract}

DESCRIPTORS: Varicose ulcer. Life style. Validation studies. Stomatherapy.

1.Prefeitura de Sorocaba - Sorocaba/SP, Brazil.

2.Universidade Estadual de Campinas - Campinas/SP, Brazil.

3.Universidade Vale do Rio Verde - Três Corações/MG, Brazil.

Correspondence author: E-mail: uiara_oliveira@hotmail.com

Received: Mar. 18, 2019 | Accepted: Aug. 16, 2019 


\section{RESUMO}

Objetivo: Construir e validar um folheto educativo para o tratamento de pacientes com úlcera de etiologia venosa. Métodos: Estudo metodológico, desenvolvido em duas etapas: construção do folheto educativo por meio de revisão da literatura e validação de conteúdo do material por juízes especialistas no assunto. Resultados: O instrumento obteve um Índice de Validade de Conteúdo (IVC) acima de 0,80; apenas um item foi modificado após sugestão dos juízes. Conclusão: $O$ folheto educativo apresentou ser de fácil compreensão e abrangente para o conteúdo.

DESCRITORES: Úlcera varicosa. Estilo de vida. Estudos de validação. Estomaterapia.

\section{RESUMEN}

Objetivo: Crea y valida un folleto educativo para el tratamiento de pacientes con úlcera de etiología venosa. Metodos: Estudio metodológico, desarrollado en dos etapas: construcción del folleto educativo por medio de revisión de la literatura y validación de contenido del material por jueces especialistas en el asunto. Resultados: El instrumento obtuvo un Índice de Validez de Contenido (IVC) por encima de 0,80; sólo un ítem fue modificado después de la sugerencia de los jueces. Conclusión: El folleto educativo se presentó de fácil comprensión y amplitud para el contenido.

DESCRIPTORES: Úlcera varicosa. Estilo de vida. Estudios de validación. Estomaterapia.

\section{INTRODUCTION}

Venous ulcers (VU) present a serious public health problem worldwide and their treatment generates a high cost for health services, patients and their families. Additionally, they have a high prevalence, between 50 and $70 \%$ of cases $^{1}$, and are more common in older people $^{2}$. Another aggravating factor is that they have long periods of existence until complete healing, and may even relapse. Literature indicates recurrence rates of $70 \%$ until the second year after tissue repair ${ }^{3}$.

In addition to the high prevalence and relapse, the presence of a VU in the body not only represents a physical change and costly expenses, but also causes psychological and social damage to the patient, including their family members ${ }^{4}$.

VU is described as a wound that appears due to a change in the functioning of skeletal muscles, veins, and valves of the venous system of lower limbs ${ }^{5}$, and it is usually located in the distal portion of the leg. This system presents as function reducing the action of gravity and facilitating venous return to the heart. Risk factors such as immobility, obesity, pregnancy, deep vein thrombosis, and trauma affect the functioning of the venous system ${ }^{6,7}$.

When this system does not perform its function properly, it causes venous hypertension ${ }^{6}$, consequent local hypoxia and cell death, and the presence of a wound. Hypoxia is explained by three hypotheses: 1) fibrin accumulation in vessels wall, such as total or partial blockage of oxygen diffusion into the tissues; 2) extravasation of macromolecules into the interstitial space, facilitating the adhesion of growth factors to the vascular wall; and 3) slowness of the flow of leukocytes that accumulate in the capillary walls, causing tissue damage ${ }^{6,8}$.

A study conducted with a sample of 318 patients with ulcers of venous etiology identified that the most frequent symptoms were: sleep disturbance (80\%), pain (74\%), edema in the lower limbs (67\%), fatigue (59\%), moderate to intense exudate (59\%), depression (50\%) and inflammatory signs in the leg tissues (18\%), thus having worse quality of life (QOL) than the general population? .

Once the VU diagnosis has been confirmed, treatment should be started. The goal of the treatment consists in reduction of venous hypertension, pain management, compression therapy, and appropriate wound treatment. Therefore, care of these patients requires comprehensive care and health education, promoting lifestyle modification ${ }^{10,11}$.

However, achieving lifestyle change is not an easy task, as it requires health education as a priority, emphasizing orientations for the evident risk factors in this population that can be implemented in the health environment ${ }^{12}$.

In addition, individuals need information that clarifies their doubts and desires about their condition, in order to follow the guidance provided by the health professional and achieve better results. 
Among orientations in guidelines, programs and expertise, the Leg Ulcer Prevention Program (LUPP) stands out, which lists the fundamental interventions for patients with VU: compression therapy, activities/exercises such as regular walking (30 min/day), heel movement and squats ( 5 movements/5 repetitions for 3 times/day), lower limb elevation (30 $\mathrm{min} / 3$ times/day), skin care, such as cleaning and hydration with neutral products, inspection (report any early changes), nutrition and adequate hydration ${ }^{13}$. Another program called Lively Legs Program maintains the orientations and reinforces the adherence to compression treatment and physical activity for the treatment of patients with venous ulcers ${ }^{14}$. In summary, guidelines direct orientations for lifestyle changes, such as encouraging adherence to compression treatment and lower limb elevation, regular skin hydration, ceasing or reducing cigarette consumption, encouraging physical activity, the use of appropriate shoes, and balanced nutrition ${ }^{10-15}$.

Among a range of exercises, trainings for the ankle, foot and calf are the most effective for VU management. A randomized clinical trial showed that exercises in this population helped in ankle mobility, favoring the reduction of the wound area, lipodermatosclerosis, and signs and symptoms of venous insufficiency ${ }^{16}$. Another study showed important clinical results regarding exercise in wound healing, in which the intervention group showed improvement in tissue repair in 10\% of individuals in the 12 -week period, and a rate of $32 \%$ reduction in the wound area compared to the control group ${ }^{17}$.

In this context, different studies highlight the importance of education and guidance to encourage this population to adhere to exercise practice ${ }^{14,16}$.

Thus, seeking to contribute to health education to change the lifestyle of people with venous ulcers, this study aimed: to build and validate an educational leaflet for the treatment of patients with ulcers of venous etiology.

\section{METHODS}

This is a methodological study with a quantitative approach conducted in the period from November 2016 to July 2017, and structured in two stages: development of the educational instrument and content validation.

For the construction of the educational brochure, a bibliographic survey was carried out in the Biblioteca
Virtual Saúde, SciELO and LILACS/Database in Nursing (BDENF) databases, in addition to consultation of books and theses in the area. The search terms were "varicose ulcer" and "lifestyle", selected in the Medical Subject Headings (MeSH) and in Descriptors in Health Sciences (DeCS, Descritores em Ciências da Saúde), with descriptors and keywords in English, Portuguese and Spanish.

Articles in the data search that were not available in full text and written in languages other than English, Spanish and Portuguese were excluded from the study. Year of publication was not selected, since it is a construction of educational material and the compilation of information is fundamental. Twenty-one articles were found in the bibliographic survey; however, only 13 were analyzed, according to the flowchart described below.

In addition to the analysis of the selected articles, in order to construct the leaflet to guide lifestyle of patients with $\mathrm{VU}$, the schooling of the individuals was taken into consideration. Therefore, aspects considered fundamental in the development of educational materials regarding language, layout and illustration were followed ${ }^{18}$ : how to use a new title for each key message and significant words to guide patients on the content of the material; use markers with concise text; use the target audience language to facilitate reading; present a friendly appearance; use numerical lists when items need to be understood in sequence; add space between paragraphs or text groups; use clear, objective and popular language; add a box to define important medical terms that cannot be replaced by simple words; use active voice; avoid jargon and scientific terms; avoid compound and complex phrases; avoid the use of abbreviations; add illustrations to improve readability; use visuals to replace text and color illustrations because they provide more meaning than black and white drawings of the same objects.

Thus, the information was written in language accessible to lay population, addressing the subject of venous ulcer, guidelines on the disease, signs and symptoms, risk factors, treatment, rest, importance of compression, physical exercise, and ankle/foot/calf exercises.

The printed leaflet was prepared under the name of Lifestyle guidelines for the treatment of venous ulcers. The artwork was prepared with the help of a graphic designer by making figures and formatting, configuring and diagramming the pages. 


\section{Content validity}

Evaluation of equivalences of the versions occurred in a quantitative and qualitative way, using the content validity index (CVI) calculation, which allows the quantitative evaluation of the extent of agreement of the experts ${ }^{19}$.

This test evaluates the level of agreement between the judges on certain aspects of the adapted questionnaire and its items. The judges scored the items with values from 1 to 4 as: 1) not equivalent; 2) impossible to evaluate equivalence without reviewing the item; 3) equivalent, but requires minor changes; and 4) absolutely equivalent ${ }^{20}$

The score was computed by adding the items that were rated with " 3 " and " 4 ", dividing the value by the number of judges. Items that received rating of " 1 " and " 2 " were reviewed. For the study, the level of agreement was set at or above $0.8^{20}$.

Items that had CVI equal to or greater than 0.8 were considered adequate and were not modified. Qualitative changes were made for items that did not reach this value and for those that, despite having a CVI greater than 0.8 , the judges suggested changes.

For this stage, the orientation leaflet was sent to judges: nurses, physiotherapists, university professors, and physical educators who work with patients with wounds, to assess the content validity. Initially, the judges received an invitation letter to participate as members of the expert committee. After acceptance, everyone received the evaluation instructions along with the leaflet. The analysis was carried out regarding relevance, clarity and comprehensiveness of the items included in the leaflet, referring to illustration, language and layout. The research project was approved by the Research Ethics Committee of the Faculty of Medical Sciences of the State University of Campinas (Unicamp) (consolidated opinion number 1,649,224). The ethical precepts of Resolution 466/12 were followed, which encompasses autonomy and privacy of the participants.

\section{RESULTS}

In the literature review, articles that were not available in full text and written in languages other than English, Spanish and Portuguese were excluded from the study. Year of publication was not selected, since it is a construction of educational material and the compilation of information is fundamental. Thus, 21 articles were found in the bibliographic survey; however, only 13 were analyzed, according to the flowchart described in Fg. 1.

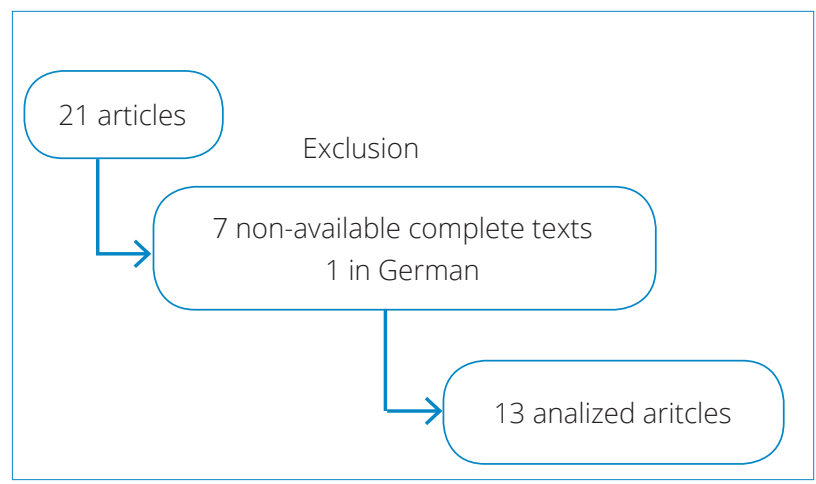

Figure 1. Flowchart of the reviewed articles.

The review, selection and adaptation of the contents for the composition of the educational material resulted in the following contents: why does the wound appear? What are the signs and symptoms of the disease? Risk factors - what makes people have that problem? Treatment; rest; importance of compression; practice of physical exercise; ankle/foot/calf exercises. The leaflet was sent to health professionals in order to obtain the evaluation of the material. Seven judges participated: three stomatherapists nurses, two nurses, one physiotherapist, and one physical educator; all of whom worked with wounded patients.

In the CVI evaluation, only the item Treatment, regarding the layout, obtained a value $<0.8$, and its modification was necessary, as shown in Table 1 . The judge requested the presence of more illustrations to facilitate the comprehensibility of patients.

As for the others, although acceptable, some suggestions were followed, such as: layout changes, more illustrations and self-explanatory figures, and replacement of some words by synonyms. It was also requested by one of the judges to put figures in the item Treatment, to facilitate understanding.

After this stage, the leaflet was used in orientations provided to patients with venous ulcers, to assist them in their evaluation in a randomized study and to evaluate the effects of strategies of a lifestyle orientation program and the healing process ${ }^{21}$. 
Table 1. Evaluation of the leaflet by the judges in relation to the CVI, São Paulo, 2018.

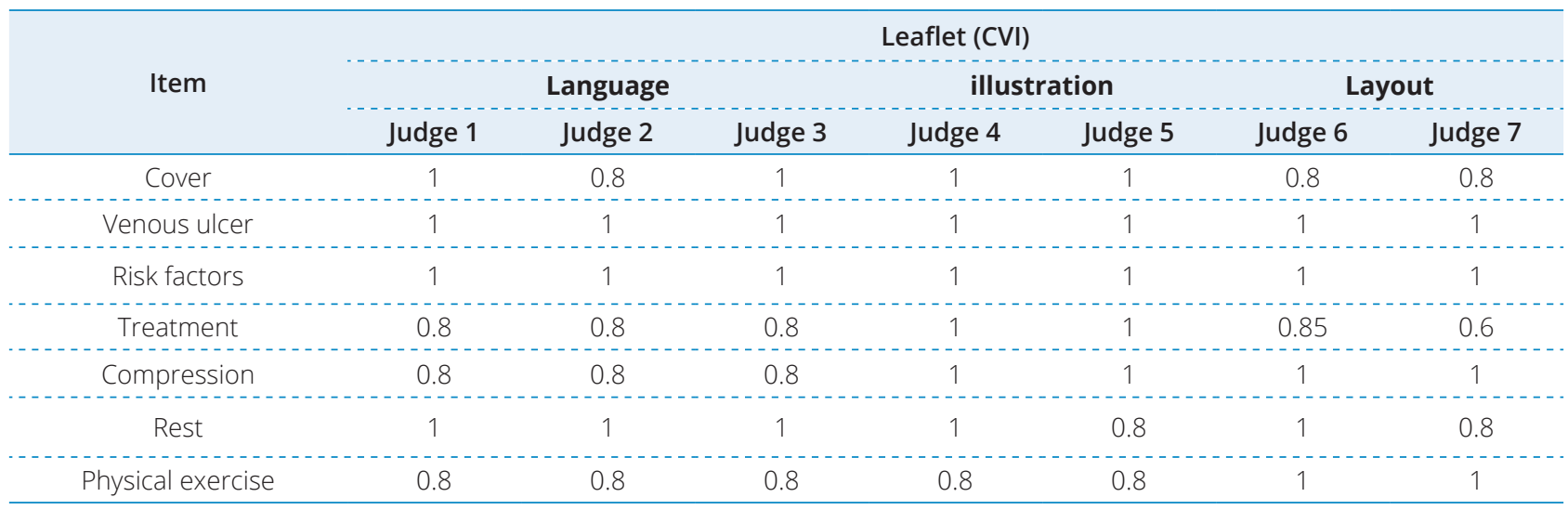

\section{DISCUSSION}

This study aimed to build and validate an educational leaflet with evidence of content validity for treatment of patients with ulcer of venous etiology.

Nursing care for the wounded person must be scientifically grounded, in order to establish a therapeutic relationship that consists of a complete data collection and survey of the problems that affect the patient's life. Subsequently, care should be individually planned, providing real answers to the needs and not only to the wound ${ }^{5}$.

For the construction of the leaflet, expertise orientations and guidelines that address the treatment of ulcer of venous etiology were followed. Adequate compression accompanied by recommendations which involve lifestyle changes, such as rest, lower limb elevation, nutrition, hydration, reduction of smoking/drug abuse, physical activity, cleansing and hydration of the skin are essential for wound treatment $t^{1,11-15}$. Therefore, these items were the points approached in the leaflet.

The aspects to be addressed for a person with venous ulcer are diverse and the literature has extensive coverage in this subject. Therefore, a few important items should be selected and the evaluation of the educational material by specialized professionals involved with the target population favors the construction of the material, since these professionals provide changes, suggestions, information and opinions that aim at the best result ${ }^{22}$.

In this context, written materials are strategies that can be used by health professionals in the education of patients to assist them in taking decisions and in self-care actions, and are essential to transmit information to patients with $\mathrm{VU}$, when it comes to lifestyle modification ${ }^{15,22}$.

The materials should convey messages in a clear and objective manner, avoiding possible misinterpretations, which can lead to inadequate practice, insufficient recall and even rejection of the provided information ${ }^{18}$. Thus, the lifestyle orientation leaflet was sent to health professionals in order to evaluate the material.

The judges analyzed the pertinence, clarity and comprehensiveness of the items included in the leaflet, in relation to illustration, language and layout, considering the orientations. During this stage, some key items for care and prevention of venous ulcers that should be available in the leaflet were highlighted, such as the management of venous ulcer. These points corroborated the international literature and guidelines on adequate compression accompanied by recommendations involving lifestyle changes, such as rest, lower limb elevation, nutrition, hydration, reduction of smoking/drug abuse, physical activity, cleansing and hydration of the skin ${ }^{10,11,13,23,24}$.

The importance of this research in the professional and social context is emphasized, since it will provide an educational leaflet for people with venous ulcers and professionals in the area to use in care, enabling the administration of a better quality care, considering the human being integrally and helping to better understand their health condition.

The availability of the leaflet will provide a tool for the action of health professionals, especially nurses, to clarify doubts in order to improve the quality of life of patients with chronic wounds. 


\section{CONCLUSION}

The educational leaflet prepared in this study obtained a CVI of 0.8 in almost all items, was easy to understand and had comprehensive content; therefore, it was validated. This tool may contribute to the process of health education of people with venous ulcers promoting forms of care in the management of ulcers and changes in lifestyle.

\section{AUTHOR'S CONTRIBUTION}

\author{
Conceptualization, Domingues EAR and Kaizer \\ UAO; Methodology, Domingues EAR and Kaizer UAO; \\ Writing - Original Draft, Domingues EAR and Kaizer \\ UAO; Writing - Review and Editing, Domingues EAR \\ and Kaizer UAO.
}

\section{REFERENCES}

1. Gillespie DL. Venous ulcer diagnosis, treatment, and prevention of recurrences. J Vasc Surg. 2010;52(5):8S-14S. https://doi.org/10.1016/j.jvs.2010.05.068

2. Alavi A, Sibbald R, Phillips T, Miller O, Margolis D, Marston W et al. What's new: management of venous leg ulcers approach to venous leg ulcers. J Am Acad Dermatol. 2016;74(4):627-40. https://doi.org/10.1016/j.jaad.2014.10.048

3. da Silva FA, Freitas CH, Jorge MS, Moreira TM, de Alcântara MC. Nursing in stomatherapy: clinical care for the patient with varicose ulcer. Rev Bras Enferm. 2009;62(6):889-93. https:// doi.org/10.1590/S0034-71672009000600014

4. Dias TYAF, Costa IKF, Melo MDM, Torres SM, Gomes SO, Maia EMC et al. Quality of life assessment of patients with and without venous ulcer. Rev Latino-Am Enfermagem. 2014;22(4):576581. https://doi.org/10.1590/0104-1169.3304.2454

5. César F, Tiago F, Ana R, Cláudia S. A pessoa com úlcera de perna, intervenção estruturada dos cuidados de enfermagem: revisão sistemática da literatura. Rev Esc Enferm USP. 2012;46:480-486. https://doi.org/10.1590/ S0080-62342012000200029

6. Casey G. Chronic wound healing: Leg ulcers. Kai Tiaki: Nurs N Z. 2011;17(11):24-29.

7. Labropoulos N, Wang ED, Lanier ST, Khan SU. Factors associated with poor healing and recurrence of venous ulceration. Plast Reconstr Surg. 2012;129(1):179-186. https:// doi.org/10.1097/PRS.0b013e3182362a53

8. Trent JT, Falabella A, Eaglstein WH, Kirsner RS. Venous ulcers: pathophysiology and treatment options - part 2. Wound Management \& Prevention [Internet]. 2005;51(5):55-56, 2005 [cited 2018 Dec 10]. Available at: https://www.o-wm.com/ content/venous-ulcers-pathophysiology-and-treatmentoptions\%E2\%80\%94part-2

9. Edwards H, Courtney M, Finlayson K, Shuter P, Lindsay E. A randomised controlled trial of a community nursing intervention: improved quality of life and healing for clients with chronic leg ulcers. J Clin Nurs. 2009;18:1541-549. https:// doi.org/10.1111/j.1365-2702.2008.02648.x
10. Hecke AV, Grypdonck M, Beele H, Bacquer DD, Defloor T. How evidence-based is venous leg ulcer care? A survey in community settings. J Adv Nurs. 2009 Feb;65(2):337-47. https://doi.org/10.1111/j.1365-2648.2008.04871.x

11. Pascarella $L$, Shortell CK. Medical management of venous ulcers. Semin Vasc Surg. 2015;28(1):21-8. https://doi. org/10.1053/j.semvascsurg.2015.06.001

12. Van Hecke A, Goeman C, Beeckman D, Heinen M, Defloor T. Development and psychometric evaluation of an instrument to assess venous leg ulcer lifestyle knowledge among nurses. J Adv Nurs. 2011;67(12):2574-85. https://doi.org/10.1111/ j.1365-2648.2011.05683.x

13. Miller C, Kapp S, Donohue L. Sustaining Behavior Changes Following a Venous Leg Ulcer Client Education Program. Healthcare. 2014;2(3):324-337. https://doi. org/10.3390\%2Fhealthcare2030324

14. Heinen M, Borm G, van der Vleuten C, Evers A, Oostendorp R, van Achterberg $T$. The Lively Legs self-management programme increased physical activity and reduced wound days in leg ulcer patients: Results from a randomized controlled trial. Int J Nurs Stud. 2012;49(2):151-56. https://doi.org/10.1016/j. ijnurstu.2011.09.005

15. Australian and New Zealand clinical practice guideline for prevention and management of venous leg ulcers [Internet]. 2011 [cited 2018 Jan 4]. Available at: http://www.awma.com. au/publications/2011_awma_vlug

16. Widener JM. Venous leg ulcers: Summary of new clinical practice guidelines published August 2014 in the Journal of Vascular Surgery. J Vasc Nurs. 2015;33(2):60-7._https://doi. org/10.1016/j.jvn.2015.01.001

17. O'Brien J, Finlayson K, Kerr G, Edwards H. Evaluating the effectiveness of a self-management exercise intervention on wound healing, functional ABPllity and health-related quality of life outcomes in adults with venous leg ulcers: a randomised controlled trial. Int Wound J. 2017;14:130-37. https://doi.org/10.1111/iwj.12571 
18. Townsend MS. Patient-driven education materials: Lowliterate adults increase understanding of health messages and improve compliance. Nurs Clin N Am. 2011;46:367-78. https://doi.org/10.1016/j.cnur.2011.05.011

19. Polit DF, Beck CT. Nursing Research: Generating and Assessing Evidence for Nursing Practice. 10th ed. Philadelphia (PA): Wolters Kluwer; 2016.

20. Alexandre, NMC, Coluci, MZO. Validade de conteúdo nos processos de construção e adaptação de instrumentos de medidas. Ciênc Saúde Coletiva. 2011;16(7):3061-068. https:// doi.org/10.1590/S1413-81232011000800006
21. Domingues EAR, Kaizer UAO, Lima MHM. Effectiveness of the strategies of an orientation programme for the lifestyle and wound-healing process in patients with venous ulcer: A randomised controlled trial. Int Wound J. 2018;15(5):798-806. https://doi.org/10.1111/iwj.12930

22. Morei a MDF, Nonrega NMLD, Silva MITD. Comunicação escrita: contribuição para elaboração de material educativo em saúde. Rev Bras Enferm. 2003;56:184-188. https://doi. org/10.1590/S0034-71672003000200015

23. Griffin」, MckennaK. Written healtheducation materials: Making them more effective. Aust Occup Ther J. 2003;50(3):170-7. https://doi.org/10.1046/j.1440-1630.2003.00381.x 